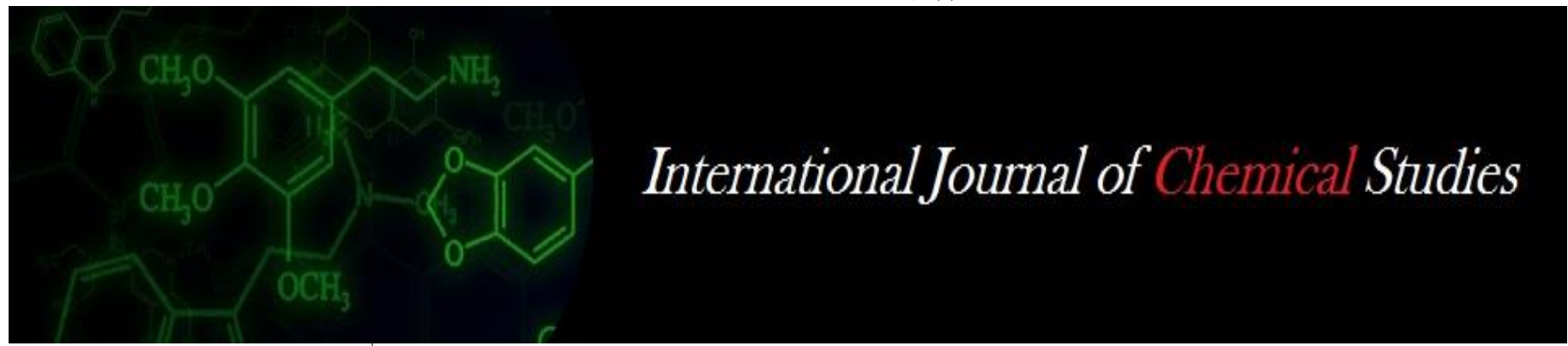

P-ISSN: 2349-8528

E-ISSN: 2321-4902

www.chemijournal.com

IJCS 2021; 9(1): 2198-2201

(C) 2021 IJCS

Received: 08-10-2020

Accepted: 17-11-2020

\section{Anjali Patel}

Department of Agronomy,

Indira Gandhi Krishi

Vishwavidyalaya Raipur,

Chhattisgarh, India

Rohit Kumar Mishra

Department of Agronomy,

Indira Gandhi Krishi

Vishwavidyalaya Raipur,

Chhattisgarh, India

Harendra Kumar

Department of Agronomy,

Indira Gandhi Krishi

Vishwavidyalaya Raipur,

Chhattisgarh, India

Kailash Vishal

Department of Plant Pathology,

Jawaharlal Nehru Krishi

Vishwavidyalaya Jabalpur,

Madhya Pradesh, India

Corresponding Author:

Anjali Patel

Department of Agronomy,

Indira Gandhi Krishi

Vishwavidyalaya Raipur,

Chhattisgarh, India

\section{Influence of integrated nutrient management on production and economics of sweet corn (Zea mays L. saccharata)}

\author{
Anjali Patel, Rohit Kumar Mishra, Harendra Kumar and Kailash Vishal
}

DOI: $\underline{\text { https://doi.org/10.22271/chemi.2021.v9.i1ae.11544 }}$

\begin{abstract}
A field experiment entitled "Influence of integrated nutrient management on production and economics of sweet corn (Zea mays L. saccharata)" was laid out during the rainy season 2019-20 at the Research farm of Ambikapur under rain fed condition. The experiment constituted of nine treatment combinations consisting three levels of organic manures $(0 \mathrm{t}, 3 \mathrm{t}$ vermicompost and $5 \mathrm{t} F Y M)$ and three levels of inorganic fertilizers $\left(50 \%, 75 \%\right.$ and 100\% RDF, where RDF is $120: 60: 40 \mathrm{~kg} \mathrm{ha}^{-1} \mathrm{~N}, \mathrm{P}_{2} \mathrm{O}_{5}$ and $\left.\mathrm{K}_{2} \mathrm{O}\right)$ and replicated trice. The result shows that growth and yield attributes, cob and fodder yield were influenced significantly by the integration of various levels of organic and inorganic fertilizers. Highest cob yield $\left(20486.7 \mathrm{~kg} \mathrm{ha}^{-1}\right)$ and the net return (₹ $\left.147265.2 \mathrm{ha}^{-1}\right)$ was registered with vermicompost @ $3 \mathrm{t} \mathrm{ha}^{-1}+$ $100 \%$ of the RDF and were found significantly fair over rest of the treatment combinations.
\end{abstract}

Keywords: Sweet corn, interactions, integrated nutrient management

\section{Introduction}

Maize (Zea mays L.) is the important cereal crop occupying a prominent position in global agriculture and it is the most important staple food crop of the world and ranks after rice and wheat. Maize is an important cereal crop due to its great adoptability to wide range of environmental conditions and production potential. Maize occupies an important place in Indian economy also known as the "Queen of Cereals". Recently specialty corns namely sweet corn, popcorn and baby corn have come out as alternate sources of food, especially for modern society. Maize growers are nowadays shifting towards the specialty corn production due to higher earning and also opening of opportunities for employment generation in peri-urban areas.

Sweet corn (Zea mays L. saccharata) is consumed as a human food as succulent grain in soft dough stage. The sugar which is $20 \%$ on dry basis at green ear stage and starch are the major component of the endosperm, results in sweetish taste of the kernel. When the grain attains $70 \%$ moisture, the cobs are picked up for canning and table purpose. The water soluble polysaccharide contented in the kernel adds texture and quality in addition to sweetness ${ }^{[15]}$. Mostly the sweet corn is grown for processing sector ending up on the super market shelves as products which include canned kernels, frozen kernels and frozen cobs. Due to being a short duration crop (65 - 70 days), it easily fits in an rainfed cropping system and in addition to sweet corn it provides green, soft, succulent, nutritious, palatable felicitous fodder to cattle ${ }^{[14]}$. Rice - rice was dominant cropping system in the Northern hills of Chhattisgarh, which is now shifting towards mono cropping of rice or maize due to climate change. With growing concern about the human health, soil quality and environmental safety, need has been felt to rethink over the prevailing agricultural practices, especially the nutrient management. Thus, organic source of nutrient supply has distinct advantages of sustainability of crop production and judicious combination of organic and inorganic fertilizers helps to sustain soil fertility since it contains mineral elements, which get changed to available forms that could be readily taken up by plants like nitrates, exchangeable phosphorous, soluble potassium, calcium, manganese etc. ${ }^{[13]}$. Sweet corn is new introduction particularly as short duration crop; so, efforts are required to standardize and economize its cultivation for maximum productivity along with sustainability and soil health. 
Although the agronomic requirements like plant geometry and fertility levels ${ }^{[14]}$ and weed control methods ${ }^{[2]}$ for sweet corn has been worked out for irrigated conditions but work on intensive cultivation of sweet corn at different nutrient management systems having both inorganic and organic sources has not been done for rainfed conditions. $100 \%$ of NPK + FYM resulted $66 \%$ increase in soil OC content over initial value. Cation exchange capacity and available nutrients were also affected similarly ${ }^{[14]}$. Application of 180:75:60 kg $\mathrm{N}: \mathrm{P}: \mathrm{K} \mathrm{ha}^{-1}+$ vermiwash at 20,35 and 50 DAS found parity with 180:75:60 kg N:P:K ha-1 + vermicompost but showed their superiority at the highest fertilization levels over the similar levels under chemical sources in enhancing green cob yield ${ }^{[7]}$.

\section{Materials and Methods}

The experiment was laid out during rainy season of 2019-20 at the Research farm of RMD College of Agriculture \& Research Station, Ambikapur which is situated at $23^{\circ} 18^{\prime} \mathrm{N}$ latitude and $83^{\circ} 15^{\prime}$ longitude and at altitude of 611 meter above mean sea level which represents the northern hills agroclimatic zone of Chhattisgarh. The experimental soil was sandy loam in texture, acidic in reaction ( $\mathrm{pH} 5.7)$, medium in organic carbon (0.56), available nitrogen (234 $\left.\mathrm{kg} \mathrm{ha}^{-1}\right)$, available phosphorus $\left(8.4 \mathrm{~kg} \mathrm{ha}^{-1}\right)$ and available potassium $\left(268 \mathrm{~kg} \mathrm{ha}^{-1}\right)$. The experiment was laid out in factorial randomized completely block design (FRCBD) with 3 repetations. The treatments consist of nine treatment combinations. The treatment comprised of two factors having three levels each, ie. Factor 1 was organics $\left(0 t, 3 t h^{-1}\right.$ vermicompost and $5 \mathrm{t} \mathrm{ha}^{-1} \mathrm{FYM}$ ) and factor 2 was inorganics $\left(50 \%, 75 \%\right.$ and $100 \% \mathrm{RDF}, \mathrm{RDF}=120: 60: 40 \mathrm{~kg} \mathrm{~N}, \mathrm{P}_{2} \mathrm{O}_{5}$, $\mathrm{K}_{2} \mathrm{O}$ ha $\left.^{-1}\right)$. Sowing was done manually in $1^{\text {st }}$ week of July 'Sugar 10' sweet corn cultivar was used. Fully decomposed farmyard manure and vermicompost were applied based on treatments. Complete manures were applied at the time of last field preparation. The nutrients were supplied as per the treatments through fertilizers namely iffco (12:32:16), urea and MOP. One third of the nitrogen and full dose of $\mathrm{P}_{2} \mathrm{O}_{5}$ and $\mathrm{K}_{2} \mathrm{O}$ were applied as basal dose at the time of sowing. However, remaining nitrogen was top dressed in two equal split doses at knee high stage at 30 DAS and tasseling stage at 45 DAS in all the treatments. Sweet corn was sown in rows of $60 \mathrm{~cm}$ apart with plant to plant distance of $15 \mathrm{~cm}$ to maintain the population of plant i.e. 111,111 plants $\mathrm{ha}^{-1}$ by using $5 \mathrm{~kg}$ $\mathrm{ha}^{-1}$ seeds. Five plants were randomly selected in each of the plot to record growth parameters viz., plant height, LAI, dry matter accumulation and CGR at different growth stages i.e. 30, 60 DAS and at harvest. Five cobs were selected randomly from each plot for determination of yield attributing characteristics of sweet corn viz., length of cob, girth of cob, no. of kernel rows $\mathrm{cob}^{-1}$ and no. of kernels row ${ }^{-1}$. Cobs from the net plot area were harvested at milky stage and weighed for cob yield. After peaking of green cobs green fodder was bundled and weighed for fodder yield. The cost of cultivation of various treatments was worked out separately. Labour and requirement of mechanical power for different operations such as land preparation, planting and harvesting was calculated as per local market rate. Benefit cost (B: C) ratio was calculated by dividing cost of cultivation by net return. All data obtained from the experiment was statistically analyzed using $F$ - test, the procedure given by ${ }^{[5]}$, critical difference (CD) values at $P=0.05$ were used to determine the significance of mean differences of treatments.

\section{Results and Discussion}

\subsection{Growth Parameters}

A significant difference in growth parameters such as plant height, leaf area index, dry matter accumulation and CGR were observed with interactions of various levels of organic and inorganic nutrients. (Table 1).

Tallest plants were recorded from the plot integrated with vermicompost @ $3 \mathrm{t} \mathrm{ha}^{-1}+100 \%$ of the RDF $(271.00 \mathrm{~cm})$ followed by FYM @ $5 \mathrm{t} \mathrm{ha}^{-1}+100 \% \operatorname{RDF}(270.93 \mathrm{~cm})$ and were found statistically superior over other treatment combinations and the smallest plants were recorded in plot treated with $0 \mathrm{t}$ organic manure $+50 \% \operatorname{RDF}(233.93 \mathrm{~cm})$. More plant height under high application of FYM and vermicompost might be due to more cell divisions and high elongation favoured by high metabolic activity as a consequence of adequate availability of nutrients. ${ }^{[12]}$ also found enhancement in height of maize crop by increasing nutrient level.

Maximum LAI at 60 DAS (5.74) were obtained with the treatment supplied with vermicompost @ $3 \mathrm{t} \mathrm{ha}^{-1}+100 \%$ RDF, found to be in parity with FYM @ $5 \mathrm{t} \mathrm{ha}^{-1}+100 \%$ RDF (5.53) but significantly higher than other combinations of various levels of organic and inorganic nutrients, while significantly minimum LAI (2.90) were recorded with $0 \mathrm{t}$ organic manure $+50 \%$ RDF. LAI gradually increased up to 60 DAS and there after deceasing trend was observed. Vermicompost Application resulted in more synthesis of vitamins, phytohormones and chlorophyll and helped the plant to intercept more solar radiation, which ultimately reflected on higher LAI in maize. This result is in close accordance with finding of ${ }^{[3,8]}$.

Crop fertilized with3 $\mathrm{t} \mathrm{ha}^{-1}$ vermicompost $+100 \%$ RDF accumulated significantly more dry matter plant ${ }^{-1}(164.94 \mathrm{~g})$ followed by $5 \mathrm{t} \mathrm{ha}^{-1} \mathrm{FYM}+100 \%$ RDF (163.59 g). Application of $0 \mathrm{t}$ organic manure $+50 \%$ RDF resulted into significantly lowest dry matter production plant ${ }^{-1}(136.83 \mathrm{~g})$. High dry matter production in FYM and vermicompost treated plots might be due to the continuous steady release of nutrients, might have enabled the leaf area duration to expand, which favouring the plants to increment the photosynthetic rate which in turn, could have led to higher accumulation of dry matter. These results were in the agreement with the findings of ${ }^{[6,9]}$.

Analysis of variance showed that the treatment vermicompost (a) $3 \mathrm{t} \mathrm{ha}^{-1}+100 \%$ RDF exhibited maximum CGR (60-75 DAS) of sweet corn, gave the value of $62.10 \mathrm{~g} \mathrm{day}^{-1} \mathrm{~m}^{-2}$ and was found to be on parity with FYM @ $5 \mathrm{t} \mathrm{ha}^{-1}+100 \%$ RDF $\left(60.22 \mathrm{~g} \mathrm{day}^{-1} \mathrm{~m}^{-2}\right)$ but significantly superior than other combinations of organics and inorganics.

\subsection{Yield attributes}

The length of cob, girth of cob, no. of kernel rows $\mathrm{cob}^{-1}$ and no. of kernels row $^{-1}$ varied significantly due to various combinations of inorganic fertilizers and organic manures (Table 2). Supply of vermicompost @ $3 \mathrm{t} \mathrm{ha}^{-1}+100 \%$ RDF resulted in highest length of cob $(19.65 \mathrm{~cm})$, girth of cob $(16.44 \mathrm{~cm})$, no. of kernel rows $\mathrm{cob}^{-1}(15.87)$ and no. of kernels row $^{-1}$ (38.67) which were on parity with the results obtained from the application of FYM @ $5 \mathrm{t} \mathrm{ha}^{-1}+100 \%$ RDF but both were significantly superior over other treatment combinations. While significantly lower cob length $(16.73 \mathrm{~cm})$, cob girth $(14.59 \mathrm{~cm})$, number of kernel rows $\mathrm{cob}^{-1}(11.50)$ and number of kernels row $^{-1}$ (31.93) were observed with $0 \mathrm{t}$ organic manure $+50 \%$ RDF. Similar observations were also made by ${ }^{[1]}$. 


\subsection{Yield}

A significant increase in green cob yield and green fodder yield were noted with various combinations of inorganic fertilizers and organic manures (Table 3). The maximum cob yield (20486.7 kg ha-1) and fodder yield $\left(23940.0 \mathrm{~kg} \mathrm{ha}^{-1}\right)$ were received by the treatment applied with of vermicompost @ $3 \mathrm{t} \mathrm{ha}^{-1}+100 \% \mathrm{RDF}$, which was significantly higher over remained treatment combinations. 0 t organic manure $+50 \%$ RDF recorded the lowest cob yield $\left(11754.4 \mathrm{~kg} \mathrm{ha}^{-1}\right)$ and fodder yield $\left(15180.0 \mathrm{~kg} \mathrm{ha}^{-1}\right)$. Significant increase in cob yield of sweet corn can be traced back to the significant increase in the yield components like length of cob, girth of cob, no. of kernel rows $\operatorname{cob}^{-1}$ and no. of kernels row ${ }^{-1}$ which had direct influence. These findings are in accordance with ${ }^{[14]}$.

\subsection{Economics}

Economics were worked out for sweet corn by taking into consideration of the input cost and market price of the crop produce. Significant variations in economic parameters were recorded due to different interactions of inorganic fertilizers and organic manures (Table 3). The maximum net return (₹147265.25 ha-1) was accrued with $3 \mathrm{t} \mathrm{ha}^{-1}$ vermicompost + $100 \%$ RDF followed by FYM @ $5 \mathrm{t} \mathrm{ha}^{-1}+100 \%$ RDF resulted ₹ $138580.78 \mathrm{ha}^{-1}$ net return. Significantly the highest $\mathrm{B}$ : C ratio (2.41) was obtained from the treatment applied with $5 \mathrm{t} \mathrm{ha}^{-1} \mathrm{FYM}+100 \%$ of the RDF. This was due to more net returns than the money spent in production of crop under this treatments. Similar results were also found by ${ }^{[10,11]}$

Table 1: Interaction effect between organic and inorganic nutrients on growth attributes of sweet corn

\begin{tabular}{|c|c|c|c|c|c|c|}
\hline Treatments & \multicolumn{6}{|c|}{ Organic manure } \\
\hline \multirow[b]{2}{*}{$\begin{array}{l}\text { Inorganic nutrient level (\% } \\
\text { recommended dose of NPK) }\end{array}$} & \multicolumn{3}{|c|}{ Plant height (cm) } & \multicolumn{3}{|c|}{ LAI } \\
\hline & $\begin{array}{l}\text { O t ha }^{-1} \text { (without } \\
\text { organic manure) }\end{array}$ & $\begin{array}{c}3 \mathrm{t} \mathrm{ha}^{-1} \\
\text { Vermicompost }\end{array}$ & $\begin{array}{l}5 \text { t ha }^{-1} \\
\text { FYM }\end{array}$ & $\begin{array}{l}\text { O t ha-1 (without } \\
\text { organic manure) }\end{array}$ & $\begin{array}{c}3 \text { t ha }^{-1} \\
\text { Vermicompost }\end{array}$ & $\begin{array}{l}5 \text { t ha }^{-1} \\
\text { FYM }\end{array}$ \\
\hline $50 \%$ & 233.93 & 243.40 & 238.33 & 2.90 & 3.42 & 3.33 \\
\hline $75 \%$ & 249.07 & 256.27 & 252.33 & 3.75 & 4.59 & 4.23 \\
\hline $100 \%$ & 266.47 & 271.00 & 270.93 & 4.76 & 5.74 & 5.53 \\
\hline S.Em \pm & \multicolumn{3}{|c|}{1.11} & \multicolumn{3}{|c|}{0.17} \\
\hline $\mathrm{CD}(\mathrm{P}=0.05)$ & \multicolumn{3}{|c|}{3.24} & \multicolumn{3}{|c|}{0.50} \\
\hline Treatments & \multicolumn{6}{|c|}{ Organic manure } \\
\hline \multirow{2}{*}{$\begin{array}{l}\text { Inorganic nutrient level (\% } \\
\text { recommended dose of NPK) }\end{array}$} & \multicolumn{3}{|c|}{\begin{tabular}{|c|} 
Dry matter accumulation \\
\end{tabular}} & \multicolumn{3}{|c|}{ CGR $\left(\mathrm{g} \mathrm{day}^{-1} \mathrm{~m}^{-2}\right)$} \\
\hline & $\begin{array}{c}\mathrm{Ot} \mathrm{ha} \mathrm{A}^{-1} \text { (without organic } \\
\text { manure) }\end{array}$ & \begin{tabular}{|c|}
$3 \mathrm{t} \mathrm{ha}^{-1}$ \\
Vermicompost
\end{tabular} & $\begin{array}{l}5 \mathrm{tha}^{-1} \\
\text { FYM }\end{array}$ & $\begin{array}{c}\mathrm{O}^{\mathrm{t} \mathrm{ha}} \mathrm{ha}^{-1} \text { (without organic } \\
\text { manure) }\end{array}$ & $\begin{array}{c}3 \mathrm{t} \mathrm{ha}^{-1} \\
\text { Vermicompost }\end{array}$ & $\begin{array}{l}5 \mathrm{t} \mathrm{ha}^{-1} \\
\text { FYM }\end{array}$ \\
\hline $50 \%$ & \begin{tabular}{|l|}
136.83 \\
\end{tabular} & 142.73 & 142.08 & 49.58 & 51.72 & 52.35 \\
\hline $75 \%$ & 145.17 & 159.66 & 156.95 & 52.41 & 60.69 & 59.70 \\
\hline $100 \%$ & 158.31 & 164.94 & 163.59 & 60.73 & 62.10 & 60.22 \\
\hline S.Em \pm & \multicolumn{3}{|c|}{0.93} & \multicolumn{3}{|c|}{0.76} \\
\hline $\mathrm{CD}(\mathrm{P}=0.05)$ & \multicolumn{3}{|c|}{2.73} & \multicolumn{3}{|c|}{2.23} \\
\hline
\end{tabular}

Table 2: Interaction effect between organic and inorganic nutrients on yield attributes of sweet corn

\begin{tabular}{|c|c|c|c|c|c|c|}
\hline Treatments & \multicolumn{6}{|c|}{ Organic manure } \\
\hline \multirow[b]{2}{*}{$\begin{array}{l}\text { Inorganic nutrient level (\%) } \\
\text { recommended dose of NPK) }\end{array}$} & \multicolumn{3}{|c|}{$\begin{array}{c}\text { Cob length }(\mathrm{cm}) \\
\end{array}$} & \multicolumn{3}{|c|}{$\begin{array}{c}\text { Cob length }(\mathrm{cm}) \\
\end{array}$} \\
\hline & $\begin{array}{l}\text { O t ha }{ }^{-1} \text { (without } \\
\text { organic manure) }\end{array}$ & $\begin{array}{c}3 \text { t ha }^{-1} \\
\text { Vermicompost }\end{array}$ & $\begin{array}{l}5 \text { t ha }^{-1} \\
\text { FYM }\end{array}$ & $\begin{array}{l}\text { O t ha } \\
\text { organic manure) }\end{array}$ & $\begin{array}{c}3 \text { t ha }^{-1} \\
\text { Vermicompost }\end{array}$ & $\begin{array}{l}5 \text { t ha }^{-1} \\
\text { FYM }\end{array}$ \\
\hline $50 \%$ & 16.73 & 17.73 & 17.28 & 14.59 & 15.46 & 15.26 \\
\hline $75 \%$ & 18.11 & 18.71 & 18.37 & 15.59 & 15.96 & 15.81 \\
\hline $100 \%$ & 18.99 & 19.65 & 19.57 & 16.01 & 16.44 & 16.33 \\
\hline S.Em \pm & \multicolumn{3}{|c|}{0.10} & \multicolumn{3}{|c|}{0.06} \\
\hline $\mathrm{CD}(\mathrm{P}=0.05)$ & \multicolumn{3}{|c|}{0.30} & \multicolumn{3}{|c|}{0.17} \\
\hline Treatments & \multicolumn{6}{|c|}{ Organic manure } \\
\hline \multirow{2}{*}{$\begin{array}{l}\text { Inorganic nutrient level (\% } \\
\text { recommended dose of NPK) }\end{array}$} & \multicolumn{3}{|c|}{ No. of kernel rows $\mathrm{cob}^{-1}$} & \multicolumn{3}{|c|}{ No. of kernels row ${ }^{-1}$} \\
\hline & $\begin{array}{c}\text { O t ha }{ }^{-1} \text { (without organic } \\
\text { manure) }\end{array}$ & \begin{tabular}{|c|}
$3 \mathrm{t} \mathrm{ha}^{-1}$ \\
Vermicompost
\end{tabular} & $\begin{array}{l}5 \mathrm{tha}^{-1} \\
\text { FYM }\end{array}$ & $\begin{array}{c}\mathrm{O} \mathrm{t} \mathrm{ha}^{-1} \text { (without organic } \\
\text { manure) }\end{array}$ & $\begin{array}{c}3 \mathrm{t} \mathrm{ha}^{-1} \\
\text { Vermicompost }\end{array}$ & $\begin{array}{l}5 \mathrm{t} \mathrm{ha}^{-1} \\
\text { FYM }\end{array}$ \\
\hline $50 \%$ & 11.50 & 13.60 & 13.50 & 31.93 & 34.80 & 34.20 \\
\hline $75 \%$ & 14.23 & 14.80 & 14.56 & 35.27 & 36.60 & 35.73 \\
\hline $100 \%$ & 15.13 & 15.87 & 15.77 & 37.00 & 38.67 & 37.87 \\
\hline S.Em \pm & \multicolumn{3}{|c|}{0.13} & \multicolumn{3}{|c|}{0.32} \\
\hline $\mathrm{CD}(\mathrm{P}=0.05)$ & \multicolumn{3}{|c|}{0.38} & \multicolumn{3}{|c|}{0.94} \\
\hline
\end{tabular}

Table 3: Interaction effect between organic and inorganic nutrients on yield $\left(\mathrm{kg} \mathrm{ha}^{-1}\right)$ and economics of sweet corn

\begin{tabular}{|c|c|c|c|c|c|c|}
\hline Treatments & \multicolumn{6}{|c|}{ Organic manure } \\
\hline \multirow[b]{2}{*}{$\begin{array}{l}\text { Inorganic nutrient level (\% } \\
\text { recommended dose of NPK) }\end{array}$} & \multicolumn{3}{|c|}{ Cob yield $\left(\mathrm{kg} \mathrm{ha}^{-1}\right)$} & \multicolumn{3}{|c|}{ Fodder yield $\left(\mathrm{kg} \mathrm{ha}^{-1}\right)$} \\
\hline & $\begin{array}{l}\text { O t ha-1 (without } \\
\text { organic manure) }\end{array}$ & $\begin{array}{c}3 \text { t ha }^{-1} \\
\text { Vermicompost } \\
\end{array}$ & $\begin{array}{l}5 \text { tha }^{-1} \\
\text { FYM }\end{array}$ & $\begin{array}{l}\text { O t ha-1 }^{-1} \text { (without } \\
\text { organic manure) }\end{array}$ & $\begin{array}{c}3 \mathrm{t} \mathrm{ha}^{-1} \\
\text { Vermicompost }\end{array}$ & \begin{tabular}{|c|}
5 t ha-1 $^{-1}$ \\
FYM \\
\end{tabular} \\
\hline $50 \%$ & 11754.4 & 13682.2 & 13442.2 & 15180.00 & 17617.33 & 17000.00 \\
\hline $75 \%$ & 14263.1 & 16460.0 & 15772.4 & 18068.89 & 20064.44 & 20115.56 \\
\hline $100 \%$ & 17228.4 & 20486.7 & 18488.9 & 21040.00 & 23940.00 & 22526.67 \\
\hline S.Em \pm & \multicolumn{3}{|c|}{346.3} & \multicolumn{3}{|c|}{281.84} \\
\hline $\mathrm{CD}(\mathrm{P}=0.05)$ & \multicolumn{3}{|c|}{1015.4} & \multicolumn{3}{|c|}{826.55} \\
\hline Treatments & \multicolumn{6}{|c|}{ Organic manure } \\
\hline
\end{tabular}




\begin{tabular}{|c|c|c|c|c|c|c|}
\hline \multirow[b]{2}{*}{$\begin{array}{l}\text { Inorganic nutrient level (\% } \\
\text { recommended dose of NPK) }\end{array}$} & \multicolumn{3}{|c|}{ Net return $\left(\mathrm{ha}^{-1}\right)$} & \multicolumn{3}{|c|}{$\mathrm{B}: \mathrm{C}$ ratio } \\
\hline & $\begin{array}{l}\mathrm{O} \text { t ha- }{ }^{-1} \text { (without } \\
\text { organic manure) }\end{array}$ & $\begin{array}{l}\mathrm{O} \mathrm{t} \mathrm{ha}^{-1} \text { (without } \\
\text { organic manure) }\end{array}$ & $\begin{array}{l}\mathrm{O} \mathrm{t} \mathrm{ha}^{-1} \text { (without } \\
\text { organic manure) }\end{array}$ & $\begin{array}{l}\mathrm{O} \mathrm{t} \mathrm{ha}^{-1} \text { (without } \\
\text { organic manure) }\end{array}$ & $\begin{array}{c}3 \mathrm{t} \mathrm{ha}^{-1} \\
\text { Vermicompost }\end{array}$ & $\begin{array}{l}5 \mathrm{tha}^{-1} \\
\text { FYM }\end{array}$ \\
\hline $50 \%$ & 73611.1 & 79107.49 & 88398.85 & 1.43 & 1.19 & 1.62 \\
\hline $75 \%$ & 98601.1 & 106567.70 & 111717.73 & 1.86 & 1.57 & 1.99 \\
\hline $100 \%$ & 128233.0 & 147265.25 & 138580.78 & 2.35 & 2.12 & 2.41 \\
\hline S.Emt & \multicolumn{3}{|c|}{3540.7} & \multicolumn{3}{|c|}{0.06} \\
\hline $\mathrm{CD}(\mathrm{P}=0.05)$ & \multicolumn{3}{|c|}{10383.5} & \multicolumn{3}{|c|}{0.18} \\
\hline
\end{tabular}

\section{Conclusion}

Growth attributes, yield attributes, green cob yield and green fodder yield of sweet corn were significantly higher with the application of vermicompost @ $3 \mathrm{t} \mathrm{ha}^{-1}$ along with 100\% RDF followed by FYM @ $5 \mathrm{t} \mathrm{ha}^{-1}$ along with $100 \%$ RDF over rest of the treatment combinations. Vermicompost @ $3 \mathrm{t} \mathrm{ha}^{-1}+$ $100 \%$ RDF produced maximum net return followed by FYM @ $5 \mathrm{tha}^{-1}+100 \% \mathrm{RDF}$.

\section{References}

1. Arun Kumar MA, Gali SK, Hebsur NS. Effect of different levels of NPK on growth and yield parameters of sweet com. Karnataka Journal Agricultural Science 2007;20(1):(at-43).

2. Arvadiya LK, Raj VC, Patel TU, Arvadia MK. Influence of plant population and weed management on weed flora and productivity of sweet corn (Zea mays). Indian Journal of Agronomy 2012;57(2):162-167.

3. Baharvand ZA, Zahedi H, Rafiee M. Effect of vermicompost and chemical fertilizers on growth parameters of three corn cultivars. Journal of Applied Science and Agriculture 2014;9(9):22-26.

4. Bharti B, Sharma RP. Long term effect of integrated nutrient management on soil properties and availability of nutrients in a Typic Hapludalfs under maize-wheat cropping. International Journal of Environmental \& Agriculture Research 2017;3(6):43-48.

5. Gomez KA, Gomez AA. Statistical procedure for Agricultural Reseach., edn 2, John Wiley \& Sons, New York 1984, 241-271.

6. Grazia JD, Tittonell PA, Germinara D, Chiesa A. Phosphorus and nitrogen fertilization in sweet corn (Zea mays L. saccharata). Spanish Journal of Agricultural Research 2003;1(2):103-107.

7. Keerthi S, UpendraRao A, Ramana AV, Tejeswara Rao $\mathrm{K}$. Effect of nutrient management practices on cob yield, protein content, NPK uptake by sweet corn and post harvest $\mathrm{N}, \mathrm{P}_{2} \mathrm{O}_{5}$ and $\mathrm{K}_{2} \mathrm{O}$. International Journal of Advanced Biological Research 2013;3(4):553-555.

8. Kour J, Jain N, Singh P, Himani. Effect of plant densities and integrated nutrient management on growth and productivity of sweet corn (Zea mays L. Saccharata). International Journal of Scientific Engineering and Research 2017;6(6):54-56.

9. Kumar MAM, Gali SK, Hebsur NS. Effect of different levels of NPK on growth and yield parameters of sweet corn. Karnataka Journal of Agricultural Sciences 2007;20(1):41-43

10. Mathukia RK, Choudhary RP, Shivran A, Bhosale N. Response of rabi sweet corn to plant geometry and fertilizer. Current Biotica 2014;7(4):294-298.

11. Nath K, Nepalia V, Singh D. Effect of integrated nutrient management on growth and yield of sweet corn (Zea mays L. saccharata). Annals of Agricultural Research New Series 2009;30(1\&2):73-76.
12. Pal MS, Bhatnagar A. Productivity and profitability of pop corn, composites and hybrid maize (Zea mays) under low nitrogen stress in Mollisols of Uttarakhand,. Madras Agricultural Journal 2012;99(4-6):259-262.

13. Rao AS, Chand S, Srivastava S. Opportunities for integrated plant nutrient supply system for crops/ cropping system in different agro-eco regions. Fertilizer news 2002;47(12):75-78.

14. Sahoo SC, Mahapatra PK. Response of sweet corn (Zea mays) to plant population and fertility levels during rabi season. Indian Journal of Agricultura1 Sciences 2007;77(11):779-781.

15. Venkatesh S, Sanjay R, Shekhar JC. Sweet corn, Speciality corn Technical Series I, Directorate of Maize Research, New Delhi 2003, 1-3. 